\section{PAPUA NEW GUINEA}

\author{
Area: 462,840 sq. km \\ Population: 3,190,000 \\ Capital: Port Moresby \\ Governor-General: Sir Kingsford Dibela \\ Minister of Police: John Giheno
}

Papua New Guinea comprises the National Capital District of Port Moresby and 19 provinces, as follows (capitals in brackets):

$\begin{array}{ll}\text { Central (Port Moresby) } & \text { New Ireland (Kavieng) } \\ \text { Chimbu (Kundiawa) } & \text { North Solomons (Arawa) } \\ \text { East New Britain (Rabaul) } & \text { Northern (Popondetta) } \\ \text { East Sepik (Wewak) } & \text { Southern Highlands } \\ \text { Eastern Highlands (Goroka) } & \text { (Mendi) } \\ \text { Enga (Wabag) } & \text { West New Britain } \\ \text { Gulf (Kerema) } & \text { (Kimbe) } \\ \text { Madang (Madang) } & \text { West Sepik (Vanimo) } \\ \text { Manus (Lorengau) } & \text { Western (Daru) } \\ \text { Milne Bay (Alotau) } & \text { Western Highlands } \\ \text { Morobe (Lae) } & \text { (Mount Hagen) }\end{array}$

\section{INTRODUCTION}

Papua New Guinea (Papua Niugini in Pidgin English) entered contemporary history in 1919 , through the merger of British New Guinea with the former German colony of Papua. Although independence from Australia was granted in September 1975, Australian influence is still predominant, and acts as one of the very few common bonds between a large number of tribal and ethnic communities. Another link has traditionally been the Royal Papua New Guinea Constabulary, formed under Australian supervision before the Pacific War and with a distinguished, unbroken tradition, despite nearly four years of Japanese occupation during World War II.

Independence has caused few alterations to the organization and duties of the Constabulary. One significant change has been the formation and expansion of a riot control unit, trained and equipped by the military, which suppressed the so-called Republic of the North Solomons on Bougainville, immediately after independence.

\section{ORGANIZATION}

The Papua New Guinea Constabulary (PNGC), which reports to the Minister of State for Police, comprises four branches: Regular Constabulary, in charge of general police duties; Field Constabulary, with officers of the field staff of the Department of District Administration (which replaced the Department of Native Affairs); Native Constabulary, staffed by indigenous people, in charge of policing settlements and some clerical work; and Special Constabulary, for emergency duties. The Constabulary is headed by a Commissioner of Police, who has been independent from the Public Services Commission since 1 July 1966.

The PNGC Headquarters is at Port Moresby, where the District Headquarters, the Criminal Investigation Branch Headquarters and the Police Barracks are also situated.

The PNGC comprises four divisions: Papua Division (HQ Port Moresby); New Guinea Islands Division (HQ Rabaul); New Guinea Coastal Division (HQ Lae); and Highlands Division (HQ Mount Hagen): Each Divisional Headquarters has a Police Superintendent in charge.

The Police Training College was formed at Bomana, near Port Moresby, in 1961. Recruits undergo a six-month training programme at the College, but before qualifying are required to complete a term of service in another force, usually in Australia. Officer candidates must pass a complementary twelve-month course at Bomana and may then attend specialist courses abroad, usually in Australia or the UK. This is the rule with officers of more senior ranks.

PNG Constabulary Headquarters, PO Box 2085, Konedobu, Port Moresby (25 9222; telex 22113)

Criminal Investigation Branch, PO Box 6001, Boroko, Port Moresby (25 5555)

Police Training College, Bomana, Port Moresby (28 1022)

Police Barracks, Gordons Estate, Port Moresby (25 4044)

\section{OPERATIONS}

Plans are being made to expand the Native Constabulary and to integrate police officers of Melanesian and other ethnic groups into the remaining branches. The success of this project depends upon overcoming old tribal differences, which remain a serious internal security problem. Riots have occurred, and are likely to occur in the future. Educational and prophylactic programmes, moderate concessions to secessionists, and improved communications, have provided some encouraging results, but much remains to be done.

Police officers on general duties are issued with truncheons and $9 \mathrm{~mm}$ Browning automatic pistols, which are usually adequate. The ever-present risk of disturbances justifies the existence of a permanent riot control force, closely associated with the Papua New Guinea Defence Force and equipped to modern high standards. Australia and the British Commonwealth are the main sources of equipment. 